\title{
Medication Administration Errors and Associated Factors Among Nurses
}

This article was published in the following Dove Press journal:

International Journal of General Medicine

\author{
Dejene Tsegaye' \\ Girma Alem (iD)' \\ Zenaw Tessema iD ${ }^{2}$ \\ Wubet Alebachew (iD) ${ }^{3}$ \\ 'Department of Nursing, College of \\ Health Sciences, Debre Markos \\ University, Debre Markos, Ethiopia; \\ ${ }^{2}$ Department of Pharmacy, College of \\ Health Sciences, Debre Markos \\ University, Debre Markos, Ethiopia; \\ ${ }^{3}$ Department of Maternal and Neonatal \\ Health Nursing, College of Health \\ Sciences, Debre Tabor University, Debre \\ Tabor, Ethiopia
}

\begin{abstract}
Introduction: Medication error has the potential to lead to harm to the patient. It is the leading cause of threatens trust in the healthcare system, induce corrective therapy, and prolong patients' hospitalization, produces extra costs and even death. This study aimed to assess medication administration error (MAE) and associated factors among nurses in referral hospitals of Ethiopia. Methods: Institutional-based, cross-sectional study design was used, and 422 study participants were selected using a simple random sampling method. Data were collected using a semi-structured and pre-tested self-administered questionnaire and observational checklist. The collected data were analyzed using descriptive and analytical statistics and binary logistic regression was done to identify factors associated with medication administration errors. P-value $\leq 0.05$ was considered statistically significant.
\end{abstract}

Results: Four hundred fourteen participants with a response rate of $98.1 \%$ were involved and $54.3 \%$ were females. The median age was 30 with IQR (28-34) years and the majority of them $(83.8 \%)$ had BSc qualification in nursing. The prevalence of MAE in this study was $57.7 \%$ and $30.4 \%$ of them made it more than three times. Wrong time $(38.6 \%)$, wrong assessment $(27.5 \%)$, and wrong evaluation $(26.1 \%)$ were the most frequently perpetuated medication administration errors. Significant association between medication administration errors and lack of training $[\mathrm{AOR}=2.20 ; 95 \% \mathrm{CI}(1.09,4.46)]$, unavailability of guideline $[\mathrm{AOR}=1.65 ; 95 \% \mathrm{CI}(1.03,2.79)]$, poor communication when face problem $[\mathrm{AOR}=3.31$; $95 \% \mathrm{CI}(2.04,5.37)]$, interruption $[\mathrm{AOR}=3.37,95 \% \mathrm{CI}(2.15,5.28)]$ and failure to follow medication administration rights $[\mathrm{AOR}=1.647 ; 95 \% \mathrm{CI}(1.00,2.49)]$ was noticed.

Conclusion: MAE was high in the study area as compared to studies from Jimma University Specialized Hospital, Adigrat and Mekelle University Hospital, and the University of Gondar Referral Hospital and hence developing guidelines, providing training, and develop strategies to minimize distracters are better to be undertaken.

Keywords: medication errors, medication administration, nurses, magnitude

\section{Background}

MAE is any preventable act that contributes to the failure of proper medication use in the treatment process resulting in harm for the patient to the extent of disability and death. ${ }^{1,2}$ It affects human relationships, threatens trust in the healthcare system as a whole, and can also destroy life. ${ }^{3-5}$ Errors in medication administration can occur through failures in any of the ten rights which are right patient, right medication, right time, right dose, right route, right education/advice, rights to refuse, right assessment, right evaluation/ response, and documentation. ${ }^{6-9}$ Health workers committed medication administration errors during the processes of ordering, prescribing, dispensing, preparing, or administration. .,7 $^{2}$
Correspondence: Zenaw Tessema Department of Pharmacy, College of Health Sciences, Debre Markos University, P. O. Box, 269, Debre Markos, Ethiopia

Email zenawlove2I@gmail.com
International Journal of General Medicine 2020:13 I62I-1632

$162 \mid$

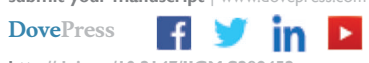

http://doi.org/| $0.2147 / 11$ GM.S289452 
Globally, medication errors are leading causes of different injuries and avoidable harms in the health care system attributing to about $10 \%$ of the overall preventable harm for hospitalized patients. ${ }^{10-12}$ In 2017, World Health Organization reported that the annual global cost associated with medication errors has been estimated to reach US (\$) 42 billion accounting for $0.7 \%$ of the total health expenditure. ${ }^{13}$ Moreover, in 2018, a British report on the prevalence and burden of medication errors estimated the occurrence of 237 million medication errors at all stages of medication administration, ${ }^{14}$ and in Finland 700 to 1700 people died each year from medication-related errors. ${ }^{15}$ Similarly, in the USA, medication errors caused the death of about 7000 patients and about 400,000 cases of avoidable patient harm per year, which cost US (\$)3.5 billion. ${ }^{2}$ In low and middle-income countries, the impact is about twice as much in terms of the number of years of healthy life lost. ${ }^{16}$

MAE is a global challenge and $18.7 \%-56 \%$ of hospitalized patients face medication administration errors and patients who faced this problem accounted for $60 \%$ to $80 \%$ in Australia and $64 \%$ in Nigeria. ${ }^{1}$

A study conducted in Tigray regional state of Ethiopia revealed that wrong dose, administering at the wrong time, medication omission, administering a wrong patient, administering via a wrong route, administering un-prescribed

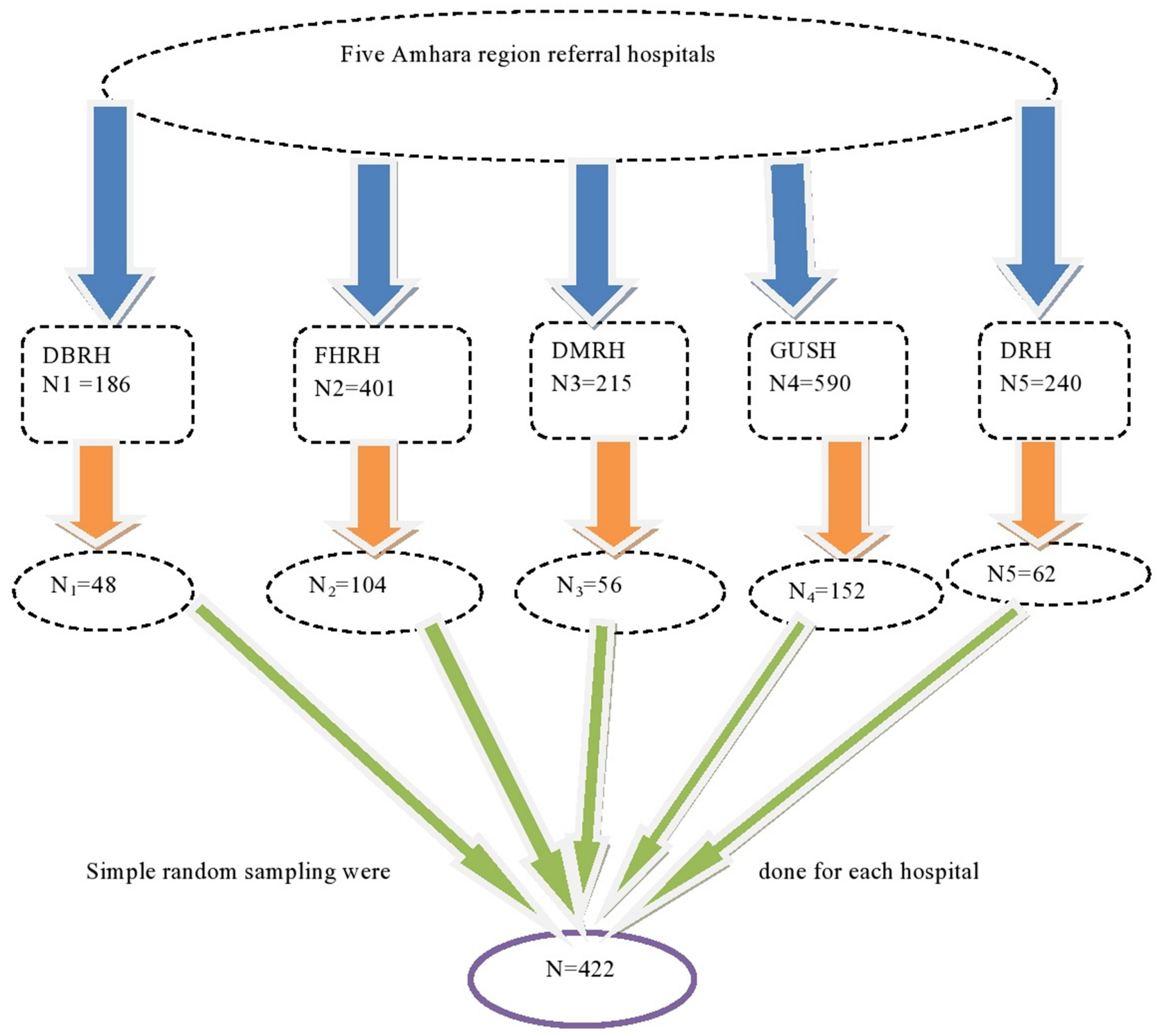

Figure I Schematic representation of the sampling procedure in the study area, $2019(n=422)$. 
medication, and administering a wrong drug were the most common types of MAE. ${ }^{17}$ As per the kinds of literature, MAE can be prevented with consistent reporting systems and by avoiding barriers to report the errors such as fear, heavy workload, time constraints, and negative employees' perceptions of error. ${ }^{18-20}$

Having a consistent reporting system and providing care based on guidelines could prevent $75 \%$ of the occurrence of harm to hospitalized patients. ${ }^{21}$ Medication administration errors can also be prevented by the use of technology like bar-coding for medications and patients, smart infusion pumps for intravenous administration, single-use medication packages, and package design features, and minimizing interruptions during the medication administration process. $^{7}$

Medication error, mainly the administration phase, is accounted to be the most common cause of disability and death throughout the world. ${ }^{22-24}$ It can also prolong patients' hospital stay resulting in increased healthcare costs for patients, families, and health professionals. ${ }^{16}$ Clinical experience observations at different public health hospitals revealed that nurses commit medication administration error administration. Normally, there are limited relevant findings concerning medication administration error in sub-Saharan African countries, especially in Ethiopia. It is the least researched and dumped health problems where significant problems related to education, economic, and trained labor is common, Besides, prior studies were merely on the six rights of medication administration and the magnitude of medication administration error and contributing factors in the study hospitals is left unknown. Therefore; the main aim of this study was to assess medication administration errors and associated factors among nurses in referral hospitals in Amhara Ethiopia.

\section{Methods}

\section{Study Area and Period}

The study was conducted among nurses working at referral hospitals of Amhara regional state which are Debre Birhan, Felegehiwot, Debre Markos, Gondar, and Dessie referral hospitals from March 1-30, 2019.

\section{Study Design}

A multicenter hospital-based cross-sectional study design triangulated with observation was conducted.

\section{Source Populations}

All nurses who were working at referral hospitals of Amhara region state.

\section{Study Populations}

Those nurses who were randomly selected from Amhara referral hospitals during the study period.

\section{Inclusion Criteria}

Nurses with a minimum of six months of working experience and involved in direct patient care were included in the study.

\section{Exclusion Criteria}

Those nurses who were not involved in medication administration practice and the ones serving in administrative positions were excluded from the study.

\section{Sample Size Determination}

Using single population proportion formula, 95\% confidence interval, $5 \%$ margin of error, a reasonable estimate for the proportion of medication administration error from

Table I Socio-Demographic Characteristics of Participants, 2019

\begin{tabular}{|c|c|c|c|}
\hline Variables & Response & $\begin{array}{l}\text { Frequency } \\
(n=4 \mid 4)\end{array}$ & $\begin{array}{l}\text { Percentage } \\
(100)\end{array}$ \\
\hline Age (years) & $\begin{array}{l}25 \text { and less } \\
26-30 \\
31-35 \\
36-40\end{array}$ & $\begin{array}{l}34 \\
193 \\
98 \\
64\end{array}$ & $\begin{array}{l}8.2 \\
46.6 \\
23.7 \\
15.5\end{array}$ \\
\hline Sex & $\begin{array}{l}4 I \text { and more } \\
\text { Female }\end{array}$ & $\begin{array}{l}25 \\
225\end{array}$ & $\begin{array}{l}6 \\
54.3\end{array}$ \\
\hline Marital status & $\begin{array}{l}\text { Male } \\
\text { Single } \\
\text { Married }\end{array}$ & $\begin{array}{l}189 \\
175 \\
232\end{array}$ & $\begin{array}{l}45.7 \\
42.3 \\
56\end{array}$ \\
\hline $\begin{array}{l}\text { Educational } \\
\text { status }\end{array}$ & $\begin{array}{l}\text { Others } \\
\text { Diploma } \\
\text { nurse } \\
\text { BSc nurse }\end{array}$ & $\begin{array}{l}7 \\
61 \\
347\end{array}$ & $\begin{array}{l}1.7 \\
14.7 \\
\\
83.8\end{array}$ \\
\hline $\begin{array}{l}\text { Educational } \\
\text { award }\end{array}$ & $\begin{array}{l}\text { MSC nurse } \\
\text { Government }\end{array}$ & $\begin{array}{l}6 \\
345\end{array}$ & $\begin{array}{l}1.5 \\
83.3\end{array}$ \\
\hline $\begin{array}{l}\text { Work } \\
\text { experience }\end{array}$ & $\begin{array}{l}\text { Private } \\
4 \text { and less } \\
5-9 \\
10-14 \\
15 \text { and more }\end{array}$ & $\begin{array}{l}69 \\
164 \\
150 \\
69 \\
31\end{array}$ & $\begin{array}{l}16.7 \\
39.6 \\
36.2 \\
16.7 \\
7.5\end{array}$ \\
\hline
\end{tabular}


a prior study $(51.8 \%),{ }^{22}$ the required sample size $(\mathrm{N})$ is calculated as follows:

$$
N=\frac{(\mathrm{Z} \alpha / 2) 2 * \mathrm{p}(1-\mathrm{p})}{\mathrm{d} 2}
$$

Where

$\mathrm{N}=$ Minimum sample size

$\mathrm{P}=$ Estimated proportion of medication administration error $(51.8 \%)$

$\mathrm{d}=$ the margin of sampling error tolerated $(5 \%)$

$Z \alpha / 2=$ is the standard normal distribution at $1-\alpha \%=$ confidence level $(95 \%=1.96)$, then

$$
N=\frac{(1.96) 20.518(1-0.518)}{(0.05) 2},
$$

\section{$\mathrm{N}=384$}

Adding a $10 \%$ non-response rate, a sample of 422 nurses were included. For the observational part of the study, since it is recommended to take a maximum of $10 \%$ of the sample size participating for cross-sectional study, 42 nurses; proportionally, 5 from DBRH, 10 from FHRH, 6 from DMRH, 15 from GUSH, and 6 from DRFH were involved.

\section{Sampling Procedure}

To select 422 nurses from the total five referral hospitals in the Amhara region, all hospitals were first listed down with their respective nurse numbers after which the sample size was proportionally allocated to each hospital. Then, the sampling frame was prepared for each hospital by having lists of nurses from the hospitals' nursing director and human resource management. Finally, eligible nurses of each hospital were selected by simple random sampling technique (Figure 1).

\section{Variables}

\section{Dependent Variable}

Prevalence of medication administration error

\section{Independent variables}

Socio-demographics characteristics, work-related factors, professional related factors, and other error producing conditions.

\section{Data Collection Tools and Procedures}

A semi-structured self-administered questionnaire was prepared and used to collect data on nurses' socio-demographic characteristics (salary, an institution where the nurse earned, an educational award, year of experience, etc), work-related

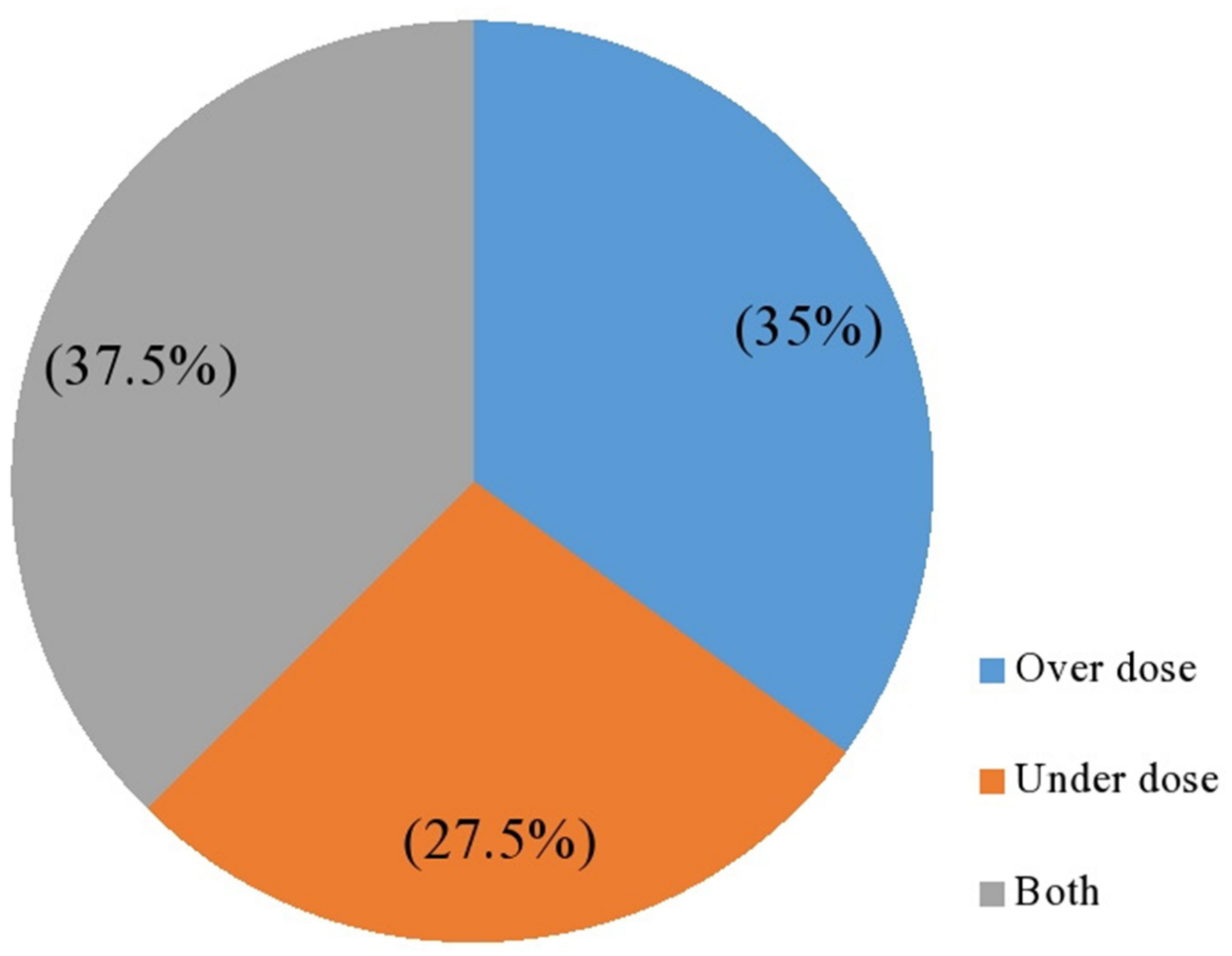

Figure 2 Dose error types committed in the study area, $2019(n=4 \mid 4)$. 
factors (nurse to patient ratio, lack of written guideline for medication administration, poor communication with other nurses while facing problems, current working unit, lack of reporting mechanism to medication errors and duration in specific unit), professional related factors (lack of training and inability to follow ten rights of medication administration practice) and other factors contributing for MAE (Unclear verbal order, illegible physicians handwriting, wrong prescription and dispensing, look like drugs, nurses' prescription in place of physicians, nurse administer medication prepared by another nurse and physicians' frequent alteration of their orders). Moreover, the prevalence of MAE, reporting trends of a medication error, and types of MAE were considered. Ten trained diploma nurses were involved in collecting data from the questionnaire. A structured observational checklist that contained nine direct observable medication administration rights was used to gather data on a total of 42 nurses' adherence to the directly observable nine rights while medication administration. Observational data collection was done by five Bsc nurses working in different units of each hospital and after observation, patients' medical records were reviewed to triangulate with a record of ordered medications' dose, route, time, and other profiles.

\section{Data Quality Control}

To assure data quality, the questionnaire and observational checklist were adapted from previous studies. ${ }^{14,22,25-31}$ Before two weeks of actual data collection, both the questionnaire and observational checklist were pretested on 21 nurses working at Finoteselam General Hospital after which some medications were made accordingly. To minimize bias, the nurses were not informed of being observed while medicating their patients. Moreover, one-day training and clear orientation were provided for data collectors and supervisors on the process of data collection. During data collection, data collectors were closely monitored and guided by five BSC nurse supervisors for complete and appropriate collection of the data, and reporting to the principal investigator was done daily. The collected data were double entered into Epidata version 4.2 for validation purposes. The entered data were multivariate analyzed for statistical adjustment of possible confounders.

\section{Data Processing and Analysis}

The collected data were cleaned manually, coded, and entered into Epi data version 4.2 and exported to STATA Version 12 statistical software for data transformation and further analysis. Descriptive statistics like frequencies, proportion, and summary statistics (mean, median, IQR, and standard deviation) were used to describe the study population with relevant variables and presented in tables and graphs. Multi-collinearity between the study variables was diagnosed using standard error and correlation matrix. The assumptions for the binary logistic regression model were first checked and then bivariable analysis was carried out to identify candidate variables $(\mathrm{p}<0.25)$ for multivariable analysis. Using these candidate variables, multivariable analysis was performed to investigate statistically significant independent predictors of medication administration error by adjusting for possible confounders. Finally, variables whose $p$-value less than $0.05(p<0.05)$ from the multivariable analysis were declared as statistically significant. An adjusted odds ratio with 95\% CI was considered to identify the strength of association between medication administration error and its predictors.

Table 2 Types of Medication Administration Error, 2019

\begin{tabular}{|c|c|c|c|}
\hline Variables & Response & $\begin{array}{l}\text { Frequency } \\
(n=4 \mid 4)\end{array}$ & $\begin{array}{l}\text { Percentage } \\
(100 \%)\end{array}$ \\
\hline Right patient & Yes & 409 & 98.8 \\
\hline \multirow[t]{2}{*}{ Right medication } & No & 5 & 1.2 \\
\hline & Yes & 401 & 96.9 \\
\hline \multirow[t]{2}{*}{ Right dose } & No & 13 & 3.1 \\
\hline & Yes & 374 & 90.3 \\
\hline \multirow[t]{2}{*}{ Right route } & No & 40 & 9.7 \\
\hline & Yes & 352 & 85 \\
\hline \multirow[t]{2}{*}{ Right time } & No & 62 & 15 \\
\hline & Yes & 254 & 61.4 \\
\hline \multirow[t]{2}{*}{ Right assessment } & No & 160 & 38.6 \\
\hline & Yes & 300 & 72.5 \\
\hline \multirow[t]{2}{*}{ Right education } & No & 114 & 27.5 \\
\hline & Yes & 307 & 74.2 \\
\hline \multirow[t]{2}{*}{ Right to refuse } & No & 107 & 25.8 \\
\hline & Yes & 310 & 74.9 \\
\hline \multirow[t]{2}{*}{ Right evaluation } & No & 104 & 25.1 \\
\hline & Yes & 306 & 73.9 \\
\hline \multirow{2}{*}{$\begin{array}{l}\text { Right } \\
\text { documentation }\end{array}$} & No & 108 & 26.1 \\
\hline & Yes & 317 & 76.6 \\
\hline \multirow{2}{*}{$\begin{array}{l}\text { Medication } \\
\text { error }\end{array}$} & No & 97 & 23.4 \\
\hline & Yes & 110 & 26.6 \\
\hline $\begin{array}{l}\text { during } \\
\text { preparation }\end{array}$ & No & 334 & 73.4 \\
\hline
\end{tabular}




\section{Ethical Consideration}

The study was conducted as per the Declaration of Helsinki since Debre Markos University provides ethical approval based on the declaration. Data were collected after verbal informed consent was approved by the ethical review committee of health Sciences College, Debre Markos University. Patients' consent for their medical records was waived by the committee since the data were already recorded for other medical cases. The individuals were told about the aim and the benefit of the study and ensured that there was no harm to them. Then, full consent was obtained from the participants before the commencement of the study. Participants were represented by a unique code to ensure data confidentiality.

\section{Results}

\section{Socio-Demographic Characteristics}

Four hundred fourteen nurses participated in this study, with a $98.1 \%$ response rate. The median age of the respondents was 30 years with interquartile range (IQR) ${ }^{27-33}$ years. Near to half $(46.6 \%)$ of them were in the age group of $26-30$ years and $56 \%$ of respondents were married. Regarding the educational level, the majority of the respondents $(83.8 \%)$ had BSc qualification in nursing. Also, most $(83.3 \%)$ of them got their current education from governmental institutions. The median work experience of respondents was 5 years (IQR 4-9) years (Table 1).

\section{Prevalence and Types of Medication Administration Error}

Out of 414 participants, $57.7 \%$ of nurses made MAE in the last 12 months and $30.4 \%$ of them made it more than three times during the specified period (Figure 2). Wrong time $(38.6 \%)$ was the most frequently perpetuated MAE followed by wrong assessment (27.5\%) and wrong evaluation (26.1\%) (Table 2). From the total dosage errors done, both overdose and underdose accounted for 37.5\% (Figure 3) whereas a total of forty route errors were made and all of these were parenteral route types. The majority of respondents (77.5) checked the expiry date of the medication before medication administration.

How many times do you commit Medication administration error?

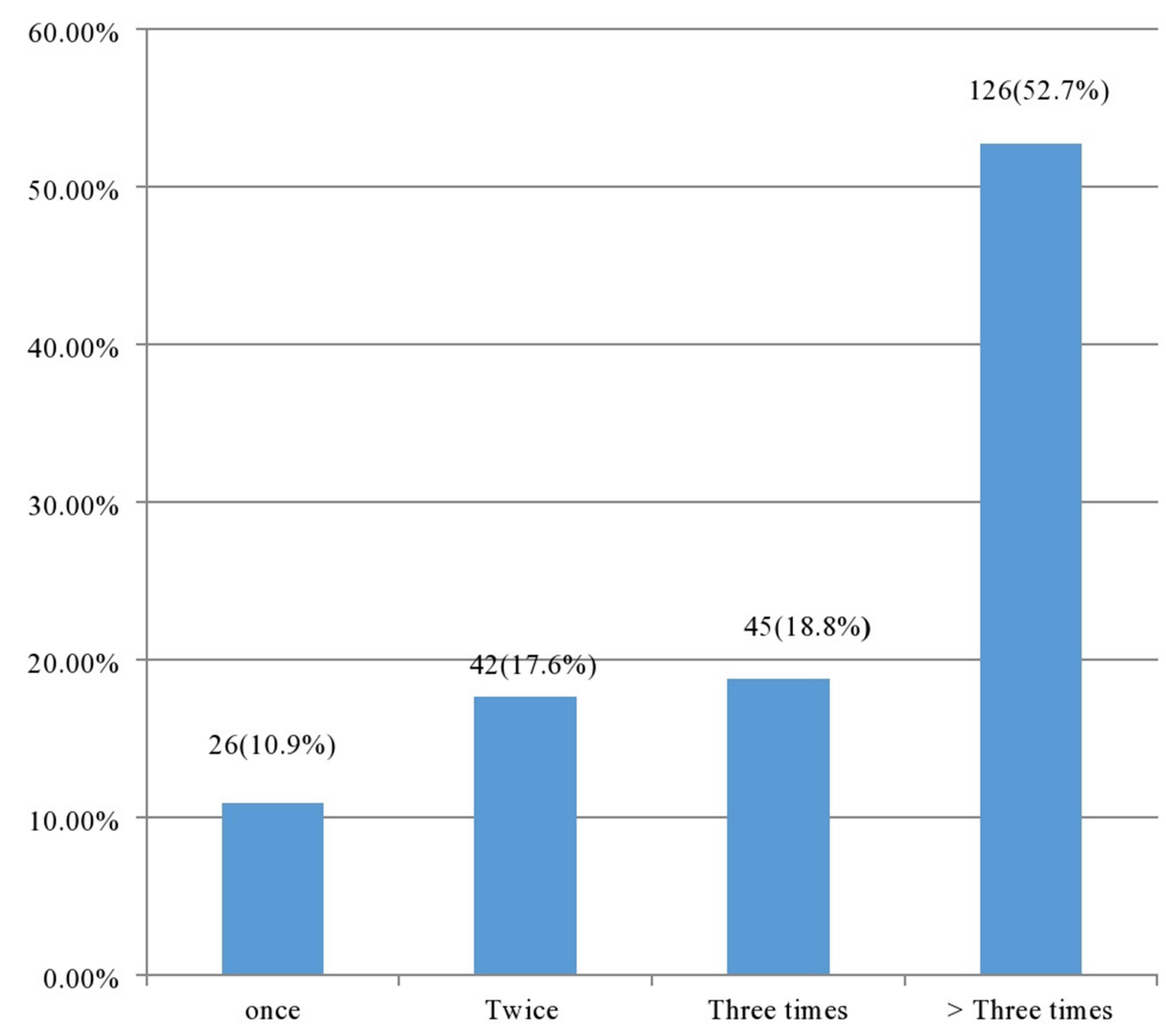

Figure 3 Frequency of medication administration errors, $2019(n=4 \mid 4)$. 


\section{Work, Managerial, and \\ Professional-Related Factors}

Near to one-fourth $(26.1 \%)$ of respondents were working in the medical ward and $72.2 \%$ of them had work experience of more than six months in their unit. The median of the nurse to patient ratio was 10 with an IQR of 4 . Most of the respondents $(88.4 \%)$ did not take training on safe medication administration practice and $43.7 \%$ did not communicate with other nurses when faced with doubt during medication administration or about the time when the next dose is due. Almost half (51.2\%) of nurses faced interruption during medication administration. Near to one-third (36.7\%) of nurses had medication administration guidelines and among them, $70.4 \%$ were using the guideline appropriately. Even though $19.6 \%$ of respondents had the system for MAE reporting, $10.43 \%$ of them did not report it in the last 12 months (Table 3) due to different reasons (Figure 4).

\section{Other Factors Contributing to a Medication Administration Error}

As per the responses of the participant, lack of sufficient training (78.7\%), physician change prescription frequently (75.1\%), and nurse provide medication prepared by another nurse $(71.5 \%)$ were the three most commonly listed contributing factors for the MAE (Table 4.)

\section{Observational Checklist Results}

To triangulate the result of the self-administered questionnaire, observational data were collected by observing nurses when administering medication at a time. The single medication administered by a nurse was considered as a single dose and a total of 109 doses of medications were observed. The results revealed that only $11 \%$ of the 109 directly observed doses of medication were administered in line with the nine directly observed rights of medication administration. Nurses' failure to educate or inform patients before administering medication (88\%) was the most observed type of error followed by failure to assess (74\%) and evaluate (66.9) patients after medicating them (Table 5).

\section{Factors Associated with Medication Administration Error}

To identify factors associated with medication administration errors, binary logistic regression was done. In bivariate logistic regression analysis, nurse's sex, marital status,
Table 3 Work-Related Characteristics of Nurses, 2019

\begin{tabular}{|c|c|c|c|}
\hline Variables & Response & $\begin{array}{l}\text { Frequency } \\
(n=4 \mid 4)\end{array}$ & $\begin{array}{l}\text { Percentage } \\
(100)\end{array}$ \\
\hline Working unit & $\begin{array}{l}\text { Medical } \\
\text { Gynecology } \\
\text { Surgical } \\
\text { Emergency } \\
\text { Pediatrics } \\
\text { Others }\end{array}$ & $\begin{array}{l}108 \\
36 \\
74 \\
100 \\
65 \\
31\end{array}$ & \begin{tabular}{l|}
26.1 \\
8.7 \\
17.9 \\
24.2 \\
15.7 \\
7.5
\end{tabular} \\
\hline $\begin{array}{l}\text { Duration in the } \\
\text { current unit }\end{array}$ & $\begin{array}{l}3 \text { and less } \\
4-5 \\
6 \text { and more }\end{array}$ & $\begin{array}{l}32 \\
83 \\
299\end{array}$ & $\begin{array}{l}7.7 \\
20 \\
72.2\end{array}$ \\
\hline $\begin{array}{l}\text { Nurse to patient } \\
\text { ratio }\end{array}$ & $\begin{array}{l}7 \text { and less } \\
8-10 \\
11 \text { and } \\
\text { more }\end{array}$ & $\begin{array}{l}96 \\
137 \\
181\end{array}$ & $\begin{array}{l}23.2 \\
31.1 \\
43.7\end{array}$ \\
\hline $\begin{array}{l}\text { Take training in MA } \\
\text { practice }\end{array}$ & $\begin{array}{l}\text { Yes } \\
\text { No }\end{array}$ & $\begin{array}{l}57 \\
366\end{array}$ & $\begin{array}{l}11.6 \\
88.4\end{array}$ \\
\hline $\begin{array}{l}\text { Have guideline for } \\
\text { MA }\end{array}$ & $\begin{array}{l}\text { Yes } \\
\text { No }\end{array}$ & $\begin{array}{l}152 \\
262\end{array}$ & $\begin{array}{l}36.7 \\
63.3\end{array}$ \\
\hline $\begin{array}{l}\text { Faced interruption } \\
\text { during MA }\end{array}$ & $\begin{array}{l}\text { Yes } \\
\text { No }\end{array}$ & $\begin{array}{l}212 \\
202\end{array}$ & $\begin{array}{l}51.2 \\
48.8\end{array}$ \\
\hline $\begin{array}{l}\text { Communicate with } \\
\text { another nurse when } \\
\text { faced with doubt }\end{array}$ & $\begin{array}{l}\text { Yes } \\
\text { No }\end{array}$ & $\begin{array}{l}233 \\
181\end{array}$ & $\begin{array}{l}56.3 \\
43.7\end{array}$ \\
\hline $\begin{array}{l}\text { Presence of } \\
\text { a reporting system } \\
\text { for MAE }\end{array}$ & $\begin{array}{l}\text { Yes } \\
\text { No }\end{array}$ & $\begin{array}{l}63 \\
351\end{array}$ & $\begin{array}{l}15.2 \\
84.8\end{array}$ \\
\hline Reporting MAE & $\begin{array}{l}\text { Yes } \\
\text { No }\end{array}$ & $\begin{array}{l}38 \\
43\end{array}$ & $\begin{array}{l}46.92 \\
53.08\end{array}$ \\
\hline
\end{tabular}

working unit, year of experiences, nurse to patient ratio, lack of training, unavailability of the guideline, faced interruption during medication administration, poor communication when faced doubt, absence of reporting system for medication administration error, failure to follow rights of medication administration error, prescription by nurses instead of physicians, and physician change orders frequently had an association with medication administration error. All variables that have an association with the outcome variables in bivariate logistic regression analyses were entered into the multivariate logistic regression analysis models by using the backward likelihood ratio method. Then lack of training, unavailability of guidelines for medication administration, interruption during medication administration, poor communication with another 


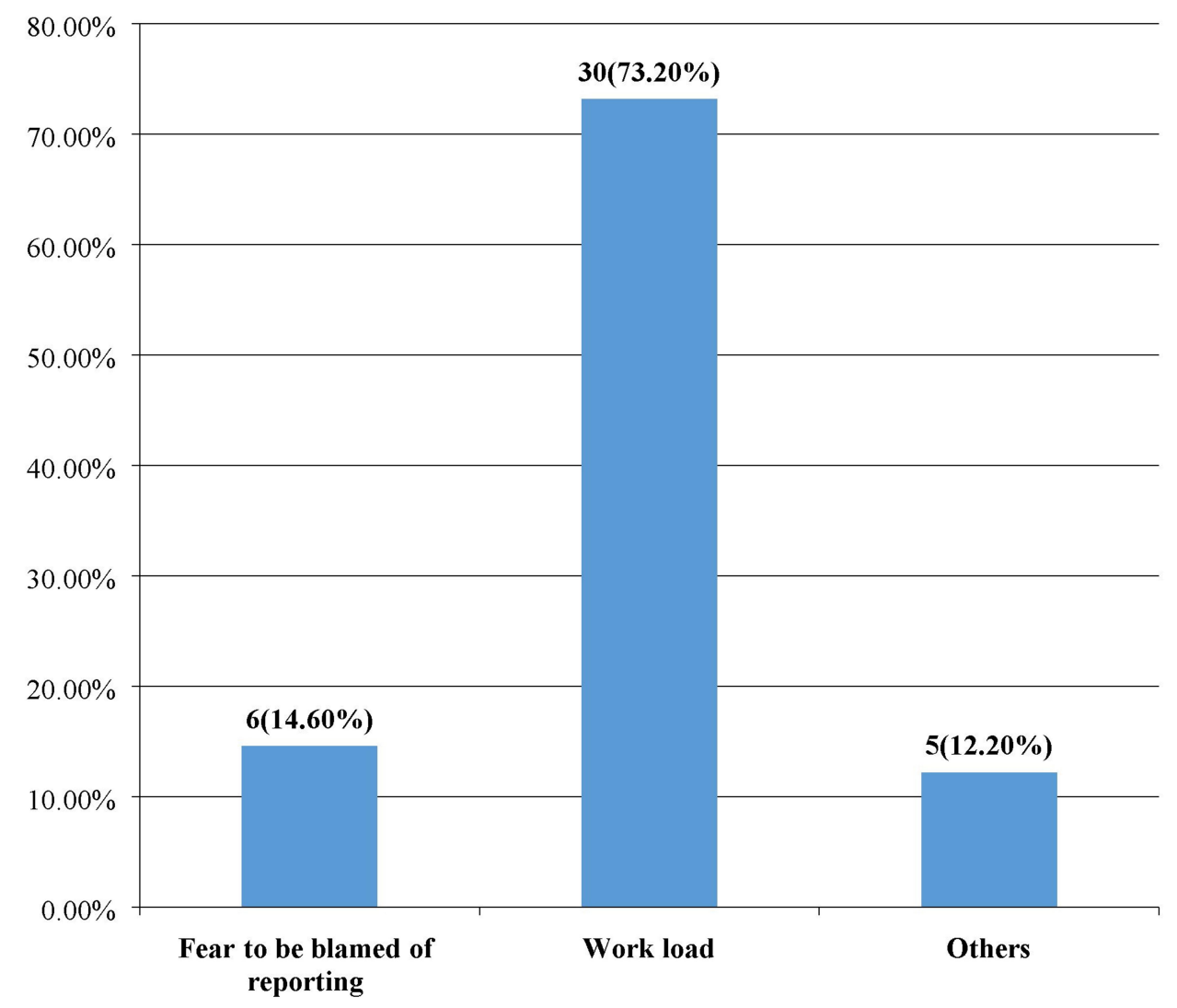

Figure 4 Reason for not reporting medication administration errors, $2019(n=414)$.

nurse when they encountered a problem, and failure to follow rights of medication administration were found significantly associated with MAE.

The odds of MAE were two times higher among nurses who did not take training on safe medication administration as compared to those nurses who had taken the training [AOR $=2.20 ; 95 \%$ CI $(1.09,4.46)]$. Similarly, the odds of MAE were almost two times higher among nurses who did not have guidelines for medication administration than had the guidelines $[\mathrm{AOR}=1.65 ; 95 \% \mathrm{CI}(1.03,2.79)]$. Nurses interrupted during medication administration and nurses who did not communicate with another nurse while facing problem were three times more likely to do medication administration error than those nurses who did not interrupt $[\mathrm{AOR}=3.37$, 95\% CI $(2.15,5.28)]$ and those nurses who communicate [AOR=3.31; 95\% CI $(2.04,5.37)]$ respectively (Table 6).

\section{Discussion}

The finding of this study showed that the magnitude of medication administration error was $57.7 \%$ with $95 \%$ CI. The prevalence of MAE in this self-reported study was relatively consistent with studies conducted at Felege
Hiwot referral hospital and research done in Kenya ${ }^{25,27}$ but much higher than a study conducted in teaching hospitals in west Iran. ${ }^{24}$ The difference might be because the previous study was done in a developed country where there is a computerized prescribing and recording system, high quality of health care institutions, voluntary error reporting system and follow up practices are common. Medication administration error was most commonly practiced at referral hospitals of Amhara region as compared Jimma University Specialized Hospital, Adigrat and Mekelle University Hospitals, and university of Gondar referral hospital. ${ }^{22,32,33}$ Although all these findings were from Ethiopian Hospitals, the constitute of medication administration, work experiences, working load, and health care systems may be attributed to deviated study results. More importantly, this study considered ten rights while the previous studies did not consider all these rights.

On the other hand, the result of this finding was lower than studies conducted in two public hospitals of Southern Ethiopia, the pediatrics ward at JUSH and teaching hospitals in Australia. ${ }^{26,30,34}$ This may be attributed to the variation in the number of hospitals considered during 
Table 4 Factors Contributing to Medication Administration Errors, 2019

\begin{tabular}{|c|c|c|c|}
\hline Variables & Response & $\begin{array}{l}\text { Frequency } \\
(n=4 \mid 4)\end{array}$ & $\begin{array}{l}\text { Percentage } \\
(100 \%)\end{array}$ \\
\hline $\begin{array}{l}\text { Lack of sufficient } \\
\text { training }\end{array}$ & $\begin{array}{l}\text { Yes } \\
\text { No }\end{array}$ & $\begin{array}{l}326 \\
88\end{array}$ & $\begin{array}{l}78.7 \\
21.3\end{array}$ \\
\hline Year of experience & $\begin{array}{l}\text { Yes } \\
\text { No }\end{array}$ & $\begin{array}{l}216 \\
298\end{array}$ & $\begin{array}{l}52.2 \\
47.8\end{array}$ \\
\hline $\begin{array}{l}\text { Insufficient staffing } \\
\text { (nurse to patient } \\
\text { ratio) }\end{array}$ & $\begin{array}{l}\text { Yes } \\
\text { No }\end{array}$ & $\begin{array}{l}293 \\
121\end{array}$ & $\begin{array}{l}70.8 \\
29.2\end{array}$ \\
\hline $\begin{array}{l}\text { Failure to follow the } \\
\text { rights of medication } \\
\text { administration }\end{array}$ & $\begin{array}{l}\text { Yes } \\
\text { No }\end{array}$ & $\begin{array}{l}174 \\
240\end{array}$ & $\begin{array}{l}42 \\
58\end{array}$ \\
\hline $\begin{array}{l}\text { Look like/sound like } \\
\text { drugs }\end{array}$ & $\begin{array}{l}\text { Yes } \\
\text { No }\end{array}$ & $\begin{array}{l}190 \\
224\end{array}$ & $\begin{array}{l}45 \\
54.1\end{array}$ \\
\hline Wrong prescription & $\begin{array}{l}\text { Yes } \\
\text { No }\end{array}$ & $\begin{array}{l}177 \\
237\end{array}$ & $\begin{array}{l}42.8 \\
57.2\end{array}$ \\
\hline Unclear verbal order & $\begin{array}{l}\text { Yes } \\
\text { No }\end{array}$ & $\begin{array}{l}204 \\
210\end{array}$ & $\begin{array}{l}49.3 \\
50.7\end{array}$ \\
\hline $\begin{array}{l}\text { Illegible handwriting } \\
\text { by prescribers }\end{array}$ & $\begin{array}{l}\text { Yes } \\
\text { No }\end{array}$ & $\begin{array}{l}220 \\
194\end{array}$ & $\begin{array}{l}53.1 \\
46.9\end{array}$ \\
\hline Wrong dispensing & $\begin{array}{l}\text { Yes } \\
\text { No }\end{array}$ & $\begin{array}{l}196 \\
218\end{array}$ & $\begin{array}{l}47.3 \\
52.7\end{array}$ \\
\hline $\begin{array}{l}\text { Interruption during } \\
\text { medication } \\
\text { administration }\end{array}$ & $\begin{array}{l}\text { Yes } \\
\text { No }\end{array}$ & $\begin{array}{l}262 \\
152\end{array}$ & $\begin{array}{l}63.3 \\
36.7\end{array}$ \\
\hline $\begin{array}{l}\text { Nurses administer } \\
\text { medication prepared } \\
\text { by another nurse }\end{array}$ & $\begin{array}{l}\text { Yes } \\
\text { No }\end{array}$ & $\begin{array}{l}296 \\
118\end{array}$ & $\begin{array}{l}71.5 \\
28.5\end{array}$ \\
\hline $\begin{array}{l}\text { Nurses write } \\
\text { a prescription in place } \\
\text { of physicians }\end{array}$ & $\begin{array}{l}\text { Yes } \\
\text { No }\end{array}$ & $\begin{array}{l}267 \\
147\end{array}$ & $\begin{array}{l}64.5 \\
35.5\end{array}$ \\
\hline $\begin{array}{l}\text { Physicians change } \\
\text { order frequently }\end{array}$ & $\begin{array}{l}\text { Yes } \\
\text { No }\end{array}$ & $\begin{array}{l}311 \\
103\end{array}$ & $\begin{array}{l}75.1 \\
24.9\end{array}$ \\
\hline
\end{tabular}

the study, involved clinical units, and setting in which the above studies were done only by involving smaller study settings and clinical units. Unlike this fact, this study involved five hospitals and more clinical units. Furthermore, some of the previous studies used an observational checklist to collect data and even used a smaller sample size as compared to this investigation.

Observationally, a total of 109 doses of medication administrations were considered of which $89 \%$ of the administered medication experienced at least one type of MAE.
Table 5 Direct Observation of Nurses' Adherence to the Directly Observable Nine Rights of Medication Administration, 2019

\begin{tabular}{|c|c|c|c|}
\hline Variables & Response & $\begin{array}{l}\text { Frequency } \\
(n=109)\end{array}$ & $\begin{array}{l}\text { Percentage } \\
(100 \%)\end{array}$ \\
\hline Right patient & Yes & 105 & 96.3 \\
\hline Right & No & 4 & 3.7 \\
\hline Medication & Yes & 97 & 89 \\
\hline \multirow[t]{2}{*}{ Right dose } & No & 12 & 11 \\
\hline & Yes & 101 & 92.6 \\
\hline \multirow[t]{2}{*}{ Right route } & No & 8 & 7.4 \\
\hline & Yes & 96 & 88 \\
\hline \multirow[t]{2}{*}{ Right time } & No & 13 & 12 \\
\hline & Yes & 62 & 56.8 \\
\hline \multirow{2}{*}{$\begin{array}{l}\text { Right } \\
\text { assessment }\end{array}$} & No & 47 & 43.2 \\
\hline & Yes & 28 & 25.6 \\
\hline \multirow[t]{2}{*}{ Right education } & No & 81 & 74.4 \\
\hline & Yes & 24 & 22 \\
\hline \multirow[t]{2}{*}{ Right evaluation } & No & 85 & 88 \\
\hline & Yes & 36 & 33 \\
\hline \multirow{3}{*}{$\begin{array}{l}\text { Right } \\
\text { documentation }\end{array}$} & No & 73 & 66.9 \\
\hline & Yes & 53 & 48.6 \\
\hline & No & 56 & 51.4 \\
\hline
\end{tabular}

The medication administration error in these study Hospitals was not as much higher than the other public hospitals in Southern Ethiopia ${ }^{26}$ and much more than a study conducted in Australia. ${ }^{30}$ Expectedly variation in the constituents of medication administration errors, the difference in study settings can contribute to the discrepancy. In developed countries the quality of services given is high. Constituents of medication administration rights can also alter the results of a particular study. The findings of both self-reported and direct observed studies showed that medication administration errors were a common health problem in the hospitals under study. This result indicated that some participants made medication administration errors but did not report in the self-reported questionnaire. Only $6.5 \%$ of nurses reported the error to the concerned body which was lower than a study conducted in $\operatorname{Iran}^{24}$ since variation in the willingness of nurses to report the errors, the availability of a system for reporting errors, and the extent of administrative support given to the nurses to report the error.

According to this study, near ten third of the medications were not administered at their regular scheduled time 
Table 6 Multivariable Logistic Regression Analysis of Factors Associated with MAE, 2019

\begin{tabular}{|c|c|c|c|c|c|c|}
\hline \multicolumn{2}{|l|}{ Variables } & \multicolumn{2}{|c|}{ MAE } & \multirow[t]{2}{*}{ COR(95\% CI) } & \multirow[t]{2}{*}{$\operatorname{AOR}(95 \% \mathrm{Cl})$} & \multirow[t]{2}{*}{ P-value } \\
\hline & & Yes & No & & & \\
\hline \multirow[t]{2}{*}{ Took training } & Yes & 17 & 40 & 1.00 & 1.00 & \\
\hline & No & 222 & 135 & $3.86(2.11-7.09)$ & $2.20(1.09-4.46)$ & $0.027^{*}$ \\
\hline \multirow[t]{2}{*}{ Have guideline } & Yes & 60 & 92 & 1.00 & 1.00 & \\
\hline & No & 179 & 83 & $3.3(2.18-5.01)$ & $1.69(1.03-2.79)$ & $0.037^{*}$ \\
\hline \multirow[t]{2}{*}{ Interruption } & Yes & 153 & 59 & $3.49(2.32-5.27)$ & $3.37(2.15-5.28)$ & $000^{*}$ \\
\hline & No & 86 & 116 & 1.00 & 1.00 & \\
\hline \multirow[t]{2}{*}{ Have communication } & Yes & 101 & 132 & 1.00 & 1.00 & \\
\hline & No & 138 & 43 & $4.19(2.73-6.44)$ & $3.31(2.04-5.37)$ & $000^{*}$ \\
\hline \multirow[t]{2}{*}{ Failure to follow 10 rights } & Yes & 116 & 58 & $1.9(1.27-2.85)$ & $1.58(1.00-2.49)$ & $0.046^{*}$ \\
\hline & No & 123 & 117 & 1.00 & 1.00 & \\
\hline
\end{tabular}

Note: *Statistical significant at $\mathrm{P}=0.05$.

(right time) leads to the patient to develop toxicities or resistance to the drugs. This finding was lower than studies done in two public hospitals in Southern Ethiopia ${ }^{26}$ but higher than the study done in teaching hospitals in west Iran $^{24}$ as there is a difference in several settings, sample sizes, the country where the studies were conducted and quality of health care services given. According to this study, a lack of sufficient training was the main contributed factor for MAE followed by frequent changes of prescription by physicians in whom both figures were supported by research done in medical and surgical units of MOI teaching and referral hospital and African hospitals. $^{25,35}$

In this study, there were factors which had a significant association with medication administration error including lack of training, poor communication with other nurses when faced problem, Interruption during medication administration, unavailability of guidelines, failure to follow ten rights of medication administration. Lack of training in this study was supported by reports from African hospitals ${ }^{35}$ and an institution-based, crosssectional study conducted in two public hospitals of Southern Ethiopia ${ }^{26}$ implicating that training is mandatory for medication error reduction as there may be new diseases, new medications, and new administration techniques. Poor communication with other nurses when they had problems was another factor significantly associated with medication administration which was similar to a study conducted in South Korea. ${ }^{36}$ Effective communication and collaboration between healthcare providers, such as open communications, error reporting, and team accountability among healthcare providers, should be facilitated and considered as a rule to reduce errors associated with medication administration and hence it is possible to reduce costs and prolonged hospitalization due to the errors and finally increase the quality of life of the patients. Interruption during medication administration was the third factor significantly associated with medication administration error and this finding was supported by research done at Felege Hiwot Referral Hospital, a systematic review in African hospitals, and two public hospitals in Southern Ethiopia. ${ }^{26,34,35}$ Interruption occurs while performing an intervention before administration is completed and its cognitive failure concerning working memory and attentiveness.

According to this study, the unavailability of the guideline was found to be significantly associated with medication administration error which was supported by research conducted in Egypt. ${ }^{1,37}$ One of WHO strategy in 2017 was to provide guidelines and strengthen health professional's capacity through skill-building. The availability of guidelines for medication administration may improve the quality of nursing care and reduce medication administration errors. Another factor that was strongly associated with medication error in this study was the failure to follow ten rights of medication administration similar to a study conducted on Korean nurse's perception of medication error working in 7 hospitals. ${ }^{36}$ Unless nurses strictly follow the ten rights of medication administration, they may perpetuate errors and affect the health care provision system as 
a whole. All these findings implied that medication administration error affects negatively the patients, patient families, the health care systems, and the health care providers in general. Besides, the problem incurs most costs and limits the financial systems of one country. Hence the respective health care professionals, administrators, government and non-governmental organizations, collaboratives, policymakers, and planers should provide significant attention for MAE and in the future intensive researches should be conducted to show the economical, social, and psychological implications of MAE which critically attributes for policymakers.

\section{Conclusion and Recommendations}

Medication administration error was high in this study and administering medication at a wrong time was the most common type of error followed by wrong assessment and evaluation respectively. Lack of training, unavailability of guidelines for medication administration, interruption during medication administration, poor communication when faced with problems and failure to follow ten rights of medication administration were factors significantly associated with medication administration errors. Therefore, stakeholders like the regional health bureau, hospital administrators, and nurse professionals should collaborate and shared respective responsible to minimize problems owing to a medication administration error.

\section{Limitation of the Study}

This study used the cross-sectional nature of the study design and does not confirm a definitive cause and effect relationship between the variables. During the observation, the study participant may change their usual way of medication administration practices (hawthorn effect) when they are told for being an understudy. Further, concerning medication administration error and reporting may be wrongly answered due to fear of the outcome or social desirability.

\section{Abbreviations}

AOR, adjusted odds ratio; $\mathrm{CI}$, confidence interval; COR, crude odds ratio; DBRH, Debre Birhan Referral Hospital; DMRH, Debre Markos Referral Hospital; DMU, Debre Markos University; DRH, Dessie Referral Hospital; FHRH, Felegehiwot Referral Hospital; GUSH, Gondar University Specialized Hospital; JUSH, Jima University Specialized Hospitals; IM, intramuscular; IV, intravenous; MAE, medication administration error; ME, medication error; OPD, outpatient department; OR, operation room; SAQ, self-administered questionnaire; SPSS, Statistical Package for Social Sciences; UK, United Kingdom; USA, United States of America.

\section{Acknowledgments}

The authors would like to acknowledge Debre Markos Universities for financial support to conduct this study.

\section{Author Contributions}

All authors made substantial contributions to conception and design, acquisition of data, or analysis and interpretation of data; took part in drafting the article or revising it critically for important intellectual content; agreed to submit to the current journal; gave final approval of the version to be published, and agree to be accountable for all aspects of the work.

\section{Funding}

This study was supported by Debre Markos University.

\section{Disclosure}

The authors report no conflicts of interest for this work.

\section{References}

1. Nkurunziza A, Chironda G, Mukeshimana M, Uwamahoro MC, Umwangange ML, Ngendahayo F. Factors contributing to medication administration errors and barriers to self-reporting among nurses: a review of the literature. Rwanda J Med Health Sci. 2019;2 (3):294-303. doi:10.4314/rjmhs.v2i3.14

2. Bennett S. WHO launches a global effort to halve medication-related errors in 5 years. 2017.

3. Elliott RA, Camacho E, Campbell F, et al. Prevalence And economic burden of medication errors in the nhs in england. 2018.

4. Case-Lo C. Medication Administration: why it's important to take drugs the right way. 2016

5. Ten rights of medication administration and management 2016. Available from: https:/ucedd.georgetown.edu/DDA/documents/ NursingRTMarch2016.pdf.

6. Salmasi S, Khan TM, Hong YH, Ming LC, Wong TW. Medication Errors in the Southeast Asian Countries: A Systematic Review. PLoS One. 2015;10(9):e0136545. doi:10.1371/journal.pone.0136545

7. Medication Administration Errors: patient safty network; 2018 Available from: https://psnet.ahrq.gov/primers/primer/47/MedicationAdministration-Errors. Accessed December 17, 2020.

8. Edwards S, Axe S. The 10 'R's of safe multidisciplinary drug administration. Nurse Prescribing. 2015;13(8):398-406. doi:10.12968/ npre.2015.13.8.398

9. WHO. The third WHO Global Patient Safety Challenge: medication Without Harm 2018 Available from: https:/www.who.int/patientsaf ety/medication-safety/en/. Accessed December 17, 2020.

10. Patel I, Balkrishnan R. Medication error management around the globe: an overview. Indian J Pharm Sci. 2010;72(5):539-545. doi:10.4103/0250-474X.78518

11. Grissinger M. Measuring up to Medication Safety In Hospitals. PT. 2009;34(1):10-50. 
12. Cousins DD, Heath WM. The National coordinating council for medication error reporting and prevention: promoting patient safety and quality through innovation and leadership. Joint Commission J Quality Patient Safety. 2008;34(12):700-702. doi:10.1016/S15537250(08)34091-4

13. Whitaker D. Medication Without Harm: the third WHO Global Patient Safety Challenge. 2017. Available from: http://newsletter. esahq.org/medication-without-harm-third-global-patient-safetychallenge/. Accessed December 17, 2020.

14. Harkanen M, Vehvilainen-Julkunen K, Murrells T, Rafferty AM, Franklin BD. Medication administration errors and mortality: incidents reported in England and Wales between 2007 2016. Res Soc Admi Pharm. 2018.

15. Mohajan HK. Medical Errors Must be Reduced for the Welfare of the Global Health Sector. Int J Public Health Health Sys. 2018;3 (5):91-101.

16. Veselik Z. Personalised, predictive and preventive medication process in hospitals - still rather missing: professional opinion survey on medication safety in Czech hospitals (based on professional opinions of recognized Czech health care experts). EPMA J. 2014;5(1):7. doi:10.1186/1878-5085-5-7

17. Baraki Z, Abay M, Tsegay L, Gerensea H, Kebede A, Teklay H. Medication administration error and contributing factors among pediatric inpatient in public hospitals of Tigray, northern Ethiopia. BMC Pediatr. 2018;18(1):1-8. doi:10.1186/s12887-018-1294-5

18. Aboshaiqah AE. Barriers in reporting medication administration errors as perceived by nurses in Saudi Arabia. Middle East J Sci Res. 2013;17(2):130-136.

19. Soydemir D, Seren Intepeler S, Mert H. Barriers to medical error reporting for physicians and nurses. West J Nurs Res. 2017;39 (10):1348-1363. doi:10.1177/0193945916671934

20. Samsiah A, Othman N, Jamshed S, Hassali MA. Knowledge, perceived barriers, and facilitators of medication error reporting: a quantitative survey in Malaysian primary care clinics. Int $J$ Clin Pharm. 2020;42(4):1118-1127. doi:10.1007/s11096-020-01041-0

21. Grol R, Wensing M, Eccles M, Davis D. Improving Patient Care: The Implementation of Change in Health Care. John Wiley \& Sons; 2013.

22. Agalu A, Ayele Y, Bedada W, Woldie M. Medication administration errors in an intensive care unit in Ethiopia. Int Arch Med. 2012;5 (1):15. doi:10.1186/1755-7682-5-15

23. Huynh N, Snyder R, Vidal JM, et al. Assessment of the nurse medication administration workflow process. $J$ Healthc Eng. 2016;2016.

24. Fathi A, Hajizadeh M, Moradi K, et al. Medication errors among nurses in teaching hospitals in the west of Iran: what we need to know about prevalence, types, and barriers to reporting. Epidemiol Health. 2017;39:39. doi:10.4178/epih.e2017022
25. Simiyu KN, El-Banna HM, Fattah MA, Omondi LA. Nurses' Medication Administration Errors at Medical-Surgical Units. Am J Nursing. 2018;7(3):88-99. doi:10.11648/j.ajns.20180703.12

26. Alemu W, Belachew T, Yimam I. Medication administration errors and contributing factors: A cross-sectional study in two public hospitals in Southern Ethiopia. Int j Africa Nursing Sci. 2017;7:68-74. doi:10.1016/j.ijans.2017.09.001

27. Feleke SA, Mulatu MA, Yesmaw YS. Medication administration error: magnitude and associated factors among nurses in Ethiopia. BMC Nurs. 2015;14(1):53. doi:10.1186/s12912-015-0099-1

28. Sadat-Ali M, Al-Shafei BA, Al-Turki RA, Ahmed SE, Al-Abbas SA, Al-Omran AS. Medication administration errors in Eastern Saudi Arabia. Saudi Med J. 2010;31(11):1257-1259.

29. Vazin A, Zamani Z, Hatam N. Frequency of medication errors in an emergency department of a large teaching hospital in southern Iran. Drug Healthc Patient Saf. 2014;6:179. doi:10.2147/DHPS.S75223

30. Westbrook JI, Rob MI, Woods A, Parry D. Errors in the administration of intravenous medications in hospital and the role of correct procedures and nurse experience. BMJ Qual Saf. 2011;20 (12):1027-1034. doi:10.1136/bmjqs-2011-000089

31. Oshikoya KA, Oreagba IA, Ogunleye OO, Senbanjo IO, MacEbong GL, Olayemi SO. Medication administration errors among pediatric nurses in Lagos public hospitals: an opinion survey. Int J Risk Saf Med. 2013;25(2):67-78. doi:10.3233/JRS130585

32. Fekadu T, Teweldemedhin M, Esrael E, Asgedom SW. Prevalence of intravenous medication administration errors: a cross-sectional study. Int Pharm Res Practice. 2017;6:47. doi:10.2147/IPRP.S125085

33. Bifftu BB, Dachew BA, Tiruneh BT, Beshah DT. Medication administration error reporting and associated factors among nurses working at the University of Gondar referral hospital, Northwest Ethiopia, 2015. BMC Nurs. 2016;15(1):43. doi:10.1186/s12912-016-0165-3

34. Yemisirach F, Biniyam G. Medication administration errors involving pediatric in-patients in a hospital in Ethiopia. Tropical J Pharm Res. 2010;9(4):401-407.

35. Mekonnen AB, Alhawassi TM, McLachlan AJ, Jo-anne EB. Adverse drug events and medication errors in African hospitals: A systematic review. Drugs Real World Outcomes. 2018;5(1):1-24. doi:10.1007/ s40801-017-0125-6

36. Kim KS, Kwon S, Kim J, Cho S. Nurses' perceptions of medication errors and their contributing factors in South Korea. J Nurs Manag. 2011;19(3):346-353. doi:10.1111/j.1365-2834.2011.01249.x

37. Tehewy F, Gad G, Gad NI, El Gafary M, Rahman SA. Medication Administration Errors in a University Hospital. J Patient Saf. 2016;12(1):34-39. doi:10.1097/PTS.0000000000000196
International Journal of General Medicine

\section{Publish your work in this journal}

The International Journal of General Medicine is an international, peer-reviewed open-access journal that focuses on general and internal medicine, pathogenesis, epidemiology, diagnosis, monitoring and treatment protocols. The journal is characterized by the rapid reporting of reviews, original research and clinical studies across all disease areas. The manuscript management system is completely online and includes a very quick and fair peer-review system, which is all easy to use. Visit http://www.dovepress.com/ testimonials.php to read real quotes from published authors. 